Winter 2014

\title{
Bitcoin: The Economic Case for a Global, Virtual Currency Operating in an Unexplored Legal Framework
}

Jonathan B. Turpin

Indiana University Maurer School of Law, jbturpin@indiana.edu

Follow this and additional works at: https://www.repository.law.indiana.edu/ijgls

Part of the International Law Commons, and the Law and Economics Commons

\section{Recommended Citation}

Turpin, Jonathan B. (2014) "Bitcoin: The Economic Case for a Global, Virtual Currency Operating in an Unexplored Legal Framework," Indiana Journal of Global Legal Studies: Vol. 21 : Iss. 1 , Article 13.

Available at: https://www.repository.law.indiana.edu/ijgls/vol21/iss1/13

This Note is brought to you for free and open access by the Law School Journals at Digital Repository @ Maurer Law. It has been accepted for inclusion in Indiana Journal of Global Legal Studies by an authorized editor of Digital Repository @ Maurer Law. For more information, please contactrvaughan@indiana.edu.

\section{$\Psi$}

JEROME HALL LAW LIBRARY

INDIANA UNIVERSITY

Maurer School of Law
Bloomington 


\title{
Bitcoin: The Economic Case for a Global, Virtual Currency Operating in an Unexplored Legal Framework
}

\author{
JONATHAN B. TURPIN ${ }^{*}$
}

\begin{abstract}
Bitcoin is a virtual currency created by programmers, which is produced at a predetermined and knowable rate to simulate a limited resource. Its value is derived from the trust of its users and is protected by its limited nature and the cryptography by which the currency is secured and authenticated. Bitcoin has been, and continues to be, used by some for the purchase of illegal substances and in furtherance of crimes. Because Bitcoin is not issued by a central bank or government, its use entails risks, both legal and otherwise, that have not previously been explored. Nonetheless, Bitcoin possesses significant economic upside over traditional currencies and methods of transaction online. As a result, governments should further study Bitcoin and regulate businesses that exchange in Bitcoin, but without attempting to stop or slow the growth of the currency itself and without attacking otherwise law-abiding citizens who transact in Bitcoins.
\end{abstract}

\section{INTRODUCTION: CURRENCY AND PAYMENT IN THE ELECTRONIC AGE}

In earlier times, currency was essentially a receipt for a commodity-redeemable in most cases for physical gold. ${ }^{1}$ Today, however, the majority of currencies are known as "fiat" currencies:

* Senior Managing Editor, Indiana Journal of Global Legal Studies, Volume 21; J.D. 2014, Indiana University Maurer School of Law; B.A. 2006, Miami University. I would like to thank my wife for her never-ending support and encouragement and my parents for instilling in me the intellectual curiosity that has carried me thus far. Please direct any questions or comments to jbturpin@indiana.edu.

1. EUROPEAN CENT. BANK, VirTUAL CURRENCY SCHEMES 9 (2012), available at http://www.ecb.int/pub/pdf/other/virtualcurrencyschemes201210en.pdf (noting this currency had no intrinsic value, but could be exchanged for a fixed quantity of the underlying commodity).

Indiana Journal of Global Legal Studies Vol. 21 \#1 (Winter 2014)

C Indiana University Maurer School of Law 
currencies that are neither inherently valuable nor redeemable for a commodity but, instead, are issued and backed by some central authority such as the United States Federal Reserve. ${ }^{2}$ The value of such currencies is derived from the trust placed in the central authority by the users of the currency. ${ }^{3}$ Transactions between individuals in close proximity to one another are simple and cost nothing. For example, you may pay your neighbor's child to mow your lawn. Neither you nor he pays any commission or fee for the money to change hands; you can simply give him paper currency. But, what if your neighbor's child is not your neighbor at all? What if he is a computer programmer in Russia? And instead of paying him to mow your lawn, you would like to pay him to develop a smartphone application for your small business. The simple act of paying for a service is no longer so simple; putting paper money in an envelope and mailing it to Russia is too risky and too slow. With approximately one third of the world's population now on the Internet, ${ }^{4}$ this is an increasingly common scenario.

Many ways now exist to send payments between individuals quickly, but these methods involve significant transaction costs. ${ }^{5}$ Companies such as PayPal, which did not exist prior to the Internet, are now major players in global commerce. ${ }^{6}$ Merchants typically take payment in the form of credit and debit cards online, but credit card companies first take their own cut, to the tune of $\$ 48$ billion per year. ${ }^{7}$ What if there was an alternative, virtual currency that only existed electronically and could be transferred anywhere in the world, in any amount, with little or no transaction cost? This is exactly the role that Bitcoin (also known as BTC) seeks to fill.

This paper will first explore the development, structure, and user base that comprises the Bitcoin network. ${ }^{8}$ Following that introduction, the focus will turn to the risks involved when choosing to transact in BTC. ${ }^{9}$ Next is an analysis of the economic implications of Bitcoin. ${ }^{10}$

2. Id.

3. Id. at 9-10.

4. Id. at 10-11.

5. Such costs are often prohibitively high, especially when the amount to be transferred is relatively low. For example, using PayPal, an international transfer using a credit card can incur transaction fees as high as 3.9\%. Fees, PAYPAL, https://www.paypal. $\mathrm{com} /$ webapps/mpp/paypal-fees (last visited Aug. 6, 2013).

6. PayPal reported $\$ 1.37$ billion in revenue for the third quarter of 2012 , suggesting its dominance in global commerce. Q3 2012 Fast Facts, PAYPAl, https://www.paypalmedia.com/assets/pdf/fact_sheet/PayPal_Q3_2012_Fast_Facts.pdf (last visited Aug. 6, 2013).

7. Albert A. Foer, Op-Ed., Our $\$ 48$ Billion Credit Card Bill, N.Y. Times, Apr. 21, 2010, at A27, available at http://www.nytimes.com/2010/04/21/opinion/21 foer.html?_r=0.

8. Infra Part I

9. Infra Part II. 
Finally, this note concludes with an analysis of the legal implications of Bitcoin and the reasons why governments around the world are, and should be, taking notice of the network ${ }^{11}$ and recommendations for methods of regulating and embracing Bitcoin. ${ }^{12}$

\section{WHAT IS BITCOIN?}

In 2009, an unknown individual or group of people, operating under the name Satoshi Nakamoto, ${ }^{13}$ published a paper outlining the framework for a proposed electronic currency. ${ }^{14}$ The paper outlined the concept behind a completely new currency-not backed by any government or redeemable for any commodity-which could be moved anonymously across borders, absent the control of any government body. ${ }^{15}$ Other developers have since taken up the roles of developing and promoting the platform. There are now five core developers, from four different countries, who have access to the Bitcoin source code, but the code itself is published online and is available for any and all to download and inspect. ${ }^{16}$ For a new version of the source code to take full effect, at least 51 percent of the network must download the new version, thereby assuring that no changes to the system may be enacted without majority agreement. ${ }^{17}$

Bitcoin is supported by a distributed network of users and relies on advanced cryptography techniques to ensure its stability and reliability. ${ }^{18} \mathrm{~A}$ Bitcoin is simply a chain of digital signatures (i.e., a string of numbers) saved in a "wallet" file. ${ }^{19}$ This chain of signatures contains the necessary history of the specific Bitcoin so that the system may verify its legitimacy and transfer its ownership from one user to another upon request. ${ }^{20} \mathrm{~A}$ user's wallet consists of the Bitcoins it

10. Infra Part III.

11. Infra Part IV.

12. Infra Part V.

13. See Joshua Davis, The Crypto-Currency, NEw YoRKER, Oct. 10, 2011, at 62, for a thorough investigation into the true identity of Satoshi Nakamoto.

14. See generally Satoshi Nakamoto, Bitcoin: A Peer-to-Peer Electronic Cash System, BITCoIN, http://www.bitcoin.org/bitcoin.pdf (last visited Mar. 11, 2014).

15. See generally id.

16. Gavin Andresen, Bitcoin: The World's First Person-to-Person Digital Currency, BITCOIN TRADING (June 20, 2011), http://www.bitcointrading.com/pdf/GavinAndresenCIA Talk.pdf. The Bitcoin source code can be downloaded at https:/www.github.com/bitcoin /bitcoin.

17. See id. (noting that Bitcoin is a "Trust No One System").

18. Nakamoto, supra note 14 , at 1 .

19. EUROPEAN CENT. BANK, supra note 1, at 23; Nakamoto, supra note 14, at 2; Andresen, supra note 16.

20. Nakamoto, supra note 14, at 2-3; Andresen, supra note 16. 
contains, a public key, and a private key. ${ }^{21}$ The public key is the address to which another party can send Bitcoins, and the private key is what enables the wallet's owner to send his own Bitcoins to someone else. ${ }^{22}$ As an analogy, the public key is your street address, and the private key is the key to your front door; others can send mail to your house with no more than your address, but no one can remove your belongings without your permission.

Satoshi Nakamoto highlighted what was perceived to be a fundamental problem with Internet commerce: the necessity for trusted third parties-financial institutions-to handle the role of payment processing and the costs imposed by those third parties. ${ }^{23}$ After all, someone must verify the authenticity of payments to prevent fraud and double spending. ${ }^{24}$ To solve this problem, Nakamoto suggested that a distributed network could take on the role of payment processing, thereby reducing transaction costs to essentially nothing. ${ }^{25}$ This distributed network would run on the processing power of individuals' personal computers, which they allow to be used in exchange for payment in Bitcoins. ${ }^{26}$

The Bitcoin network attempts to ensure the anonymity of every transaction, despite the fact that each transaction must be published for verification. ${ }^{27}$ The structure of the network requires the public disclosure of every transaction so that they may be authenticated, but the identities of the parties to each transaction are kept anonymous. ${ }^{28}$ This is most analogous to the way a stock market releases information about every trade that takes place, but without identifying the parties involved. ${ }^{29}$ It is possible, however, if the owner of a key's identity were compromised, to identify other transactions from the same owner. ${ }^{30}$ For example, if user A transfers BTC to user B, he is, by necessity, now aware of one of user B's public keys. ${ }^{31}$ If A so chooses, he may then monitor the network, look for future transactions involving that key,

21. Nikolei M. Kaplanov, Comment, Nerdy Money: Bitcoin, the Private Digital Currency, and the Case Against Its Regulation 5 (Temple Univ. Legal Studies Research Paper, 2012), available at http://ssrn.com/abstract=2115203; Andresen, supra note 16.

22. Andresen, supra note 16.

23. Nakamoto, supra note 14, at 1.

24. See id.

25. See id. at 2-3 (suggesting a timestamp server as a means for reducing transaction costs).

26. Id. at 4. For discussion of Bitcoin "mining," see infra Part I.B.

27. See id. at 2.

28. Id. at 6 .

29. Id.

30. Andresen, supra note 16.

31. Id. 
and follow the trail of at least some portion of the Bitcoins that he initially sent. ${ }^{32}$ However, B may take any of several steps to avoid such detection. For example, he may use one of the many methods of laundering Bitcoins. ${ }^{33}$ Alternatively, user B may choose to use a shared online wallet; where transactions are conducted from a large pool of BTC rather than individual accounts. ${ }^{34}$ This makes it impossible, in theory, to identify individual actors' transactions so long as the operator of the shared wallet does not keep identifying records. ${ }^{35}$

To summarize, Bitcoin is an unbacked, unregulated form of virtual currency that allows for transactions that are faster, cheaper, and more anonymous than any other existing scheme. ${ }^{36}$ In many ways, it is the closest digital equivalent of cash. ${ }^{37}$

\section{A. How is the Network Secured?}

With a network like Bitcoin, the inherent difficulty that must be overcome is the problem of transaction verification. ${ }^{38}$ That is, how do recipients know that the Bitcoins they are sent are authentic? Some method of policing is necessary to ensure that Bitcoins are not fraudulently duplicated or spent multiple times. For traditional Internet commerce, payment processors fulfill this need by validating every transaction while also taking their own share. ${ }^{39}$ Satoshi Nakamoto's solution to this problem was for a distributed network to serve as the processing point. ${ }^{40}$

The Bitcoin network is supported by the processing power of computers dedicated to the purpose by individuals around the world.41 At any given time, between twenty and thirty thousand computers are online making up the network. ${ }^{42}$ Every time a transaction is made, some of the nodes in the network verify the transaction as having occurred at

32. See id.

33. See discussion infra Part IV.B.1.

34. Id.

35. See id.

36. See EUROPEAN CENT. BANK, supra note 1, at 21.

37. Id. at 25 .

38. Nakamoto, supra note 14 , at 2-3.

39. Id. at 1.

40. See id. at 2-3.

41. See Andresen, supra note 16.

42. Id. 
a specific time. ${ }^{43}$ Thus, if someone tries to spend a Bitcoin twice, the one that occurred first in time is valid, and the second is not. ${ }^{44}$

Fraud, through stealing back previously spent Bitcoins, would only be possible if one were to possess processing power in such excess that he could not only operate faster than the rest of the entire Bitcoin network, but could also replicate the network's past work to "steal" Bitcoins. ${ }^{45}$ At the current size of the network, this is not likely feasible. ${ }^{46}$ Even if someone were able to harness more computing power than the entire rest of the network combined, that person would most likely decide that simply mining and collecting new Bitcoins would be more profitable than undermining the value of the very item he was stealing. ${ }^{47}$ But, if theft were the preferred approach, an attacker would only be able to take back Bitcoins that were previously transferred; an attacker would not be able to create new coins or steal those belonging to others that were not first transferred. ${ }^{48}$ Thus, the integrity of the system is protected by the system itself. ${ }^{49}$

\section{B. How Do You Get Bitcoins?}

There are essentially three ways to procure Bitcoins: (1) by "mining" them; (2) by purchasing them; or (3) by selling something and accepting payment in BTC.

New Bitcoins are only produced through the process known as mining. Every time a Bitcoin is transferred from one wallet to another, a complex computing process must be undertaken to verify that the transaction is legitimate (i.e., that the sender is the legitimate owner of the coin and has not sent it to multiple others). ${ }^{50}$ Because there is no central server to undertake this operation, it is carried out in the various nodes of the distributed network that make up the Bitcoin

43. See Nakamoto, supra note 14, at 3-4; Andresen, supra note 16.

44. See Nakamoto, supra note 14, at 2; Andresen, supra note 16. The actual work that is done by the network is far more complex than this, but outside the scope of this note. For the purposes of this note, it will suffice to say that the network utilizes cryptography to ensure the integrity of the system. See J.P. \& G.T., Bits and Bob, ECONOMIST, (June 13, 2011, 8:30 PM), http://www.economist.com/blogs/babbage/2011/06/virtual-currency, for a more thorough, but approachable, explanation of the cryptography that supports the system.

45. See Nakamoto, supra note 14 , at 3 .

46. See J.P. \& G.T., supra note 44.

47. EUROPEAN CENT. BANK, supra note 1, at 24 ; Nakamoto, supra note 14 , at 4.

48. Nakamoto, supra note 14 , at 6 .

49. See id. at 4.

50. See Nakamoto, supra note 14 , at $2-3$. 
system. ${ }^{51}$ These are simply users, known as "miners," who have chosen to run the relevant software that undertakes the necessary calculations to support the network. ${ }^{52}$ As payment, every time an operation is successfully carried out, the system generates a set amount of Bitcoins and distributes them to the successful miner. ${ }^{53}$ The difficulty of the operation, and consequently the rate at which new Bitcoins are generated, is automatically adjusted to achieve a steady, predetermined rate. ${ }^{54}$ To control inflation by limiting the total number of Bitcoins in existence, the rate at which new coins are generated will halve approximately every four years so that the total number of Bitcoins in existence may never exceed twenty-one million. ${ }^{55}$ Thus, for the time being, the network is supported entirely by the creation of new Bitcoins. This, however, will not last forever. The rate of Bitcoin generation will slow over time and will stop altogether around 2040 as the total number of Bitcoins reaches its upper limit of twenty-one million. ${ }^{56}$ Though the declining rate of Bitcoin generation will make mining less profitable over time, the need for computing power to support the network will remain. ${ }^{57}$ For this reason, miners will be able to charge transaction fees for their services, and this is how the network will support itself in the long-term. ${ }^{58} \mathrm{But}$, given the structure of the network, the cost of a single transaction will be negligible. ${ }^{59}$

It is believed that Bitcoin mining has not yet proven profitable.60 The costs required to develop a significant amount of processing power have proven to be higher than the returns in generated Bitcoins. ${ }^{61}$ This problem will likely be exacerbated as the rate of new Bitcoin generation decreases. Early miners hold out hope that, eventually, as Bitcoins become much more valuable, the investment will prove worthwhile.62 Given the current value of Bitcoins, it is possible that this point has recently been reached. Regardless, many miners are more motivated by

51. See id. at 4; Andresen, supra note 16.

52. Adrianne Jeffries, Miner Problem: Big Changes Are Coming for Bitcoin's Working Class, VERGE (Nov. 16, 2012, 9:43 AM), http://www.theverge.com/2012/11/16/3649784/bit coin-mining-asics-block-reward-change.

53. See Nakamoto, supra note 14 , at 4.

54. See Jeffries, supra note 53; Kaplanov, supra note 21, at 8.

55. EUROPEAN CENT. BANK, supra note 1, at 25; Jeffries, supra note 53. However, because Bitcoins are divisible to 8 decimal places, there will ultimately be 2.1 quadrillion of the smallest units in circulation (known as "satoshis"). Andresen, supra note 16.

56. EUROPEAN CENT. BANK, supra note 1, at 25.

57. See Nakamoto, supra note 14, at 4.

58. See EUROPEAN CENT. BANK, supra note 1, at 25.

59. See Nakamoto, supra note 14 , at 4.

60. See Jeffries, supra note 53.

61. See id.

62. Id. 
an interest in the experimental currency than by the desire for financial gain. ${ }^{63}$

The easiest way to obtain Bitcoins is to purchase them through an exchange. Though there are many exchanges, ${ }^{64}$ the underlying concept is simple: users can trade traditional currency (e.g., dollars, Euros) for BTC at the current exchange rate. ${ }^{65}$ Exchange rates are determined by supply and demand. ${ }^{66}$ Users may then store their Bitcoins in a wallet file on their personal computer or on the exchange's servers, giving them the ability to access their Bitcoins from any computer. ${ }^{67}$

\section{Who is Using Bitcoins?}

The European Central Bank estimated that there were 10,000 Bitcoin users sharing 6.5 million BTC in June of 2011.68 In' September 2011, researchers counted how many clients had accessed the network in the previous twenty-four hours in an attempt to determine how many people were using the Bitcoin network. ${ }^{69}$ At that time, there were sixtythousand clients. ${ }^{70}$ As of August 2013, there were approximately 11.5 million BTC in circulation. ${ }^{71}$

Bitcoin has drawn many early adopters because of its independence from central banks and government control. ${ }^{72}$ Spending just a few minutes in the online Bitcoin Forums, one encounters frequent references to the problems of modern currencies that exist and are, in their opinion, regulated at the whim of central bankers. ${ }^{73}$ For these individuals, a completely transparent open-source currency, secured by cryptography, is a positive alternative to traditional currency. ${ }^{74}$

63. See id.

64. Including Bitomat, Britcoin, Intersango, ExchangeBitcoin.com, Camp BX, Bitcoin7, VirtEx, VirWox, and WM-Center. EUROPEAN CENT. BANK, supra note 1, at 21 n.3.

65. Id. at 21 .

66. Id. at 6.

67. See BlockCHAIN, http://www.blockchain.info (last visited Aug. 6, 2013), for one example of an online-hosted wallet.

68. EUROPEAN CENT. BANK, supra note 1, at 25.

69. How Many People Use Bitcoin?, BITCOIN WIKI, https://en.bitcoin.it/wiki/Introduc tion\#How_many_people_use_Bitcoin.3F (last modified Sept. 18, 2013, 9:45 PM).

70. $I d$.

71. Total Bitcoins in Circulation, BLOCKCHAIN, http://blockchain.info/charts/totalbitcoins? showDataPoints=true\&timespan=\&daysAverageString $=1 \&$ scale $=0 \&$ address $=$ (last visited Aug. 6, 2013).

72. Andresen, supra note 16 (using the term "open-money" to describe Bitcoin as it was not subject to manipulation by central bankers).

73. See BITCOIN FoRUM, https://bitcointalk.org (last visited Mar. 11, 2014).

74. See Andresen, supra note 16. 
In theory, Bitcoins should be extremely attractive to merchants. Not only do they bypass the traditional model of accepting payment via credit card and paying significant transaction fees to credit card companies, but Bitcoin transactions are also irreversible. Thus, Bitcoin erases the problem of "chargebacks" that plagues merchants when allegedly fraudulent credit card activity is reversed. ${ }^{75}$ At present, there are two large obstacles for merchants who might consider accepting payment in BTC. The first is the exchange rate volatility. ${ }^{76}$ For merchants who price their wares or services in traditional currencies, settling on a price in BTC can be very difficult when the value can experience a 40 percent swing in as little as one day. ${ }^{.77}$ The second factor is the question of legality. ${ }^{78} \mathrm{As}$ the legal status of Bitcoin becomes more clearly understood, businesses will be better able to decide whether or not to accept payment in BTC. ${ }^{79}$

Despite the risks and uncertainties, the number of merchants willing to accept payment in Bitcoin continues to grow. Many of these merchants are entities that sell virtual goods and services, such as online casinos and video games. ${ }^{80}$ However, there are an increasing number of merchants selling real world goods. ${ }^{81}$ There is at least one instance of a business paying its Chinese suppliers in BTC. ${ }^{82}$ As research for a podcast about Bitcoin, one reporter was able to purchase a sandwich using BTC, ${ }^{83}$ and one can even buy alpaca socks in the currency ${ }^{84}$ In addition, a Houston defense attorney has announced that he will accept payment from his clients in Bitcoin. ${ }^{85}$

75. See id.

76. Id. See also infra Part II.A.

77. See Andresen, supra note 16.

78. See Joel Falconer, Bitcoin, the Peer-to-Peer Currency that Hopes to Change the World, NEXT WEB (June 5, 2011, 8:30 AM), http://thenextweb.com/insider/2011/06/05/ bitcoin-the-peer-to-peer-currency-that-hopes-to-change-the-world/. See also infra Part III.A.

79. See Falconer, supra note 80.

80. Id.

81. See Trade, BITCoIN WIKI, https://en.bitcoin.it/wiki/Trade (last modified Oct. 15, 2013, 1:53 PM), for a list of merchants currently accepting payment in Bitcoin.

82. See Joel Falconer, Bitcoin: Alive and Here to Stay? Or Slowly Fading Away?, NEXT WEB (Sept. 2, 2012, 9:00 PM), http://thenextweb.com/insider/2012/09/02/bitcoin-alive-stay. or-slowly-fading-away/.

83. The Tuesday Podcast: Bitcoin, NPR PLANET MONEY (July 12, 2011, 6:44 PM), http://www.npr.org/blogs/money/2011/07/13/137795648/the-tuesday-podcast-bitcoin.

84. Falconer, supra note 80.

85. Martha Neil, My Clients Can Pay Me in Bitcoins, Criminal Defense Lawyer Says, A.B.A. J. (May 1, 2013, 3:52 PM), http://www.abajournal.com/news/article/criminal_ defense_lawyer_says_clients_can_pay_him_in_bitcoins/. 
One emerging business that is making it easier for merchants to accept payment in BTC is BitPay. ${ }^{86}$ BitPay handles the payment processing in BTC for retailers, allowing them to focus on other aspects of their business. ${ }^{87}$ BitPay is the payment processor for the most visible addition to the Bitcoin network, WordPress. ${ }^{88}$ As the most popular blog publishing site, WordPress hosts sixty million blogs in 120 different languages, including The New York Times and CNN.89 Because other payment options like PayPal are blocked in sixty countries around the world, WordPress's acceptance of BTC makes it significantly easier for users in those countries to fund their websites. ${ }^{90}$

\section{INHERENT RISKS ACCOMPANYING BITCOIN}

\section{A. Value Fluctuation}

Currently, the greatest risk faced by those who hold some portion of their wealth in Bitcoins is the result of exchange rate volatility. Following a wave of publicity, the value of a Bitcoin rose to nearly thirty-two dollars in June of 2011, despite having never traded for more than a dollar until April 2011.91 However, following several high profile thefts, the value crashed to ten cents on June 20, 2011.92 The price has since recovered and soared. As of February 7, 2014, Bitcoins are being exchanged for approximately $\$ 697 .{ }^{93}$

The volatility of Bitcoin arises from a number of factors, but the most significant are the lack of widespread adoption by consumers, the lack of acceptance by merchants, and the reliance on speculation. ${ }^{94}$ As the user base grows, one would expect volatility to decrease. ${ }^{95}$ The willingness of consumers to adopt the currency likely hinges on their

86. See BITPAY, https://bitpay.com/ (last visited Aug. 6, 2013).

87. Monetarists Anonymous, ECONOMIST, Sept. 29, 2012, available at http://www.economist.com/node/21563752.

88. Andy Skelton, Pay Another Way: Bitcoin, WoroPress.com (Nov. 15, 2012, 10:21 PM), http://en.blog.wordpress.com/2012/11/15/pay-another-way-bitcoin/.

89. Caleb Allison, Bitcoin Makes Mainstream Moves, NAT'L BUS. REV., http://nbr.co.nz larticle/bitcoin-makes-mainstream-moves-ca-133891 (last visited Mar. 11, 2014).

90. Skelton, supra note 90.

91. EuRopean CENT. BANK, supra note 1, at 38; Adrianne Jeffries, The Bernie Madoffs of Bitcoin? As Market Heats Back Up, Virtual Hedge Funds Claim Fantastical Profits, VERGE (Aug. 15, 2012, 2:27 PM), http://www.theverge.com/2012/8/15/3243200/bitcoinponzi-schemes-savings-and-trust.

92. EUROPEAN CENT. BANK, supra note 1, at 38.

93. See MT. Gox, https://mtgox.com (last visited Feb. 7, 2014), for the current exchange rates for Bitcoin in U.S. Dollars.

94. EUROPEAN CENT. BANK, supra note 1 , at 38.

95. Id. 
confidence in its value. ${ }^{96}$ Consumers do not want to risk holding their wealth in a currency that they are unable to sell. However, the growth of virtual currencies can be reasonably expected as a result of Internet and electronic commerce growth and the ability of these currencies to operate faster, more anonymously, and with lower transaction costs than traditional alternatives. ${ }^{97}$ Confidence will likely grow as the network becomes larger and less volatile, but the legal uncertainties surrounding Bitcoin, and virtual currencies in general, also hamper trust. ${ }^{98}$ Nonetheless, the volatility of Bitcoin appears to be decreasing. ${ }^{99}$

\section{B. Theft and Fraud}

Thieves and scammers have long threatened holders of traditional currency. 100 Those who take what is not rightfully their own have devised countless methods for doing so, ranging from the simple mugging to highly complex Ponzi schemes run by individuals like Bernie Madoff. ${ }^{101}$ Individuals who choose to keep a portion of their wealth in BTC face similar risks. Though the network itself is incredibly secure, and the risk of counterfeiting or hacking the system is very low, users' digital wallets are not immune from risk. These risks are most easily grouped into two distinct categories: theft and fraud.

Users who store their wallets on their personal computers risk theft if they do not adequately protect themselves with anti-virus measures and backup their computers-or at least their wallet files-regularly. ${ }^{102}$ In 2011, security experts uncovered malicious software tasked with stealing Bitcoins from victims' computers and transferring them to a server under the thieves' control. ${ }^{103}$ Conversely, users who store their wallets online put their trust in the service provider's integrity and antitheft measures. One such service provider was robbed of more than $\$ 12,000$ of users' funds when hackers were able to gain access to

96. See id.

97. Id. at 47.

98. See id. at 40. See also infra Part III.A. (discussing these legal uncertainties).

99. Monetarists Anonymous, supra note 89.

100. See generally Orin S. Kerr, A Theory of Law, 16 GREEN BAG 2D 111 (2012).

101. See generally Robert Lenzner, Bernie Madoff's $\$ 50$ Billion Ponzi Scheme, FORBES.COM (Dec. 12, 2008, 6:45 PM), http://www.forbes.com/2008/12/12/madoff-ponzihedge-pf-ii-in_rl_1212croesus_inl.html (discussing Madoff's famous Ponzi scheme).

102. EUROPEAN CENT. BANK, supra note 1, at 21.

103. Kim Zetter, FBI Fears Bitcoin's Popularity with Criminals, WIRED (May 9, 2012, 10:51 PM), http://www.wired.com/threatlevel/2012/05/fbi-fears-bitcoin/. 
brokerage accounts due to the site's operators' failure to take available security precautions. ${ }^{104}$

In perhaps the most visible instance of alleged theft, a service provider has been accused of stealing the funds of its depositors. Bitcoinica was one of many Bitcoin currency exchanges that emerged to allow individuals to convert traditional currency into BTC. 105 The site was operated by someone using the name Zhou Tong, who claimed to be a seventeen-year-old from Singapore. ${ }^{106}$ Users of the site were told in 2011 that hackers had stolen more than sixty thousand BTC from the exchange in two separate attacks. ${ }^{107}$ Tong promised that users would be repaid 50 percent of their lost deposits. ${ }^{108}$ Many users suspected foul play, alleging that Tong stole the funds, and a lawsuit, now filed in San Francisco, accuses Bitcoinica of breach of contract, negligence, and other charges. ${ }^{109}$ Whether the suit will be successful, and what funds might be recoverable, remain uncertain. ${ }^{110}$

Rather than forcibly taking an innocent user's Bitcoins by hacking or another method, nefarious individuals have also been known to trick victims into giving away their Bitcoins without compensation. ${ }^{111}$ Relatively new to the Bitcoin scene, programs labeling themselves as investment funds have begun to spring up around the Bitcoin network. ${ }^{112}$ Many of these funds promise rates of return in excess of 12

104. Robert McMillan, Hackers Pull Off $\$ 12,000$ Bitcoin Heist, WIRED (Mar. 7, 2013, 3:13 PM), http://www.wired.com/wiredenterprise/2013/03/digital-thieves-pull-off-12000-bit coin-heist/?cid=co6246174.

105. See Adrianne Jeffries, Bitcoin Woes: Users File Lawsuit Over $\$ 460 \mathrm{k}$ in Missing Funds, VERGE (Aug. 10, 2012, 4:20 PM), http://www.theverge.com/2012/8/10/3233711/se cond-bitcoin-lawsuit-is-filed-in-california.

106. Id.

107. Id.

108. Id.

109. Id. See also Complaint, Cartmell v. Bitcoinica LP, No. CGC-12-522983 (Cal. Super. Ct. Aug. 6, 2012), available at https://docs.google.com/file/d/0B_ECG6JRZs-7dTZ5QS0xc UkxQjQ/edit?pli=1\#.

110. See Jeffries, supra note 107.

111. One such scheme involves creating two listings under different names: one offering to sell an amount of Bitcoins, and one looking to buy the same amount. As long as the involved parties don't use some method to verify the identities of their transaction partners, the scam artist tells his buyer to transfer funds via PayPal to his seller. Once the funds are received, the seller sends the Bitcoins to the scammer, who then disappears, leaving the buyer high and dry, without either his money or his Bitcoins. Such a scam can easily be avoided through the use of established exchanges or identity verification, but the fact remains that users continue to transact one on one using PayPal to transfer money, and open themselves up to this type of fraud. See generally Resolving Between Persons, BITCOIN FORUM, https://bitcointalk.org/index.php?topic=14045.0 (last visited Mar. 11, 2014).

112. See Jeffries, supra note 93. 
percent per month. ${ }^{113}$ Not surprisingly, the strategies on which these funds will supposedly achieve such remarkable results are undisclosed.114 According to Gavin Andresen, Bitcoin's lead developer, such funds are almost certainly Ponzi schemes. ${ }^{115}$

One such "fund," operating under the very legitimate sounding name "Bitcoin Savings \& Trust" (BST), ${ }^{116}$ promised weekly returns of 7 percent for investments of twenty-five thousand BTC (more than a quarter of a million dollars in August 2012). ${ }^{117}$ Ironically, BST claimed to be achieving such stunning returns by carrying out arbitrage-the same scheme utilized by Charles Ponzi himself. ${ }^{118}$ Despite months of online cries that it was clearly a scam and that such returns are simply not possible (legitimately), ${ }^{119}$ users continued to invest their money with the fund before it was abruptly shuttered on August 17, 2012.120 At the time of its closure, BST claimed to have as much as 500,000 BTC. ${ }^{121}$ Though the fund's operator periodically appeared online to reassure his "investors" that their funds would be returned to them, deadlines repeatedly passed with only renewed promises to repay, and the likelihood that any substantial amount of users will ever recover their investments seems doubtful at best. ${ }^{122}$ On July 23, 2013, the Securities and Exchange Commission (SEC) announced charges against Trendon T. Shavers, the man alleged to have been behind BST, for defrauding investors in a Ponzi scheme. ${ }^{123}$ At the time the charges were announced, the value of the stolen Bitcoins exceeded $\$ 60$ million. ${ }^{124}$

113. Id.

114. See id.

115. Id.

116. Not so legitimate sounding was the operating user's pseudonym: pirateat40. Id.

117. $I d$.

118. Willard Foxton, Bitcoin 'Pirate' Scandal: SEC Steps in Amid Allegations that the Whole Thing was a Ponzi Scheme, TELEGRAPH, http://blogs.telegraph.co.uk/technology/wil lardfoxton2/100007836/bitcoin-pirate-scandal-sec-steps-in-amid-allegations-that-thewhole-thing-was-a-ponzi-scheme/ (last updated Sept. 27, 2012).

119. See generally Bryan Micon's List of BTC Ponzi Schemes that Should Not be Listed as "Lending," BITCOIN FORUM, https://bitcointalk.org/index.php?topic $=94900.0$ (last visited Aug. 6, 2013) (discussing the likelihood that users were being scammed).

120. Adrianne Jeffries, Suspected Multi-Million Dollar Bitcoin Pyramid Scheme Shuts Down, Investors Revolt, VERGE (Aug. 27, 2012, 3:43 PM), http://www.theverge.com/2012 /8/27/3271637/bitcoin-savings-trust-pyramid-scheme-shuts-down.

121. $I d$.

122. See id.

123. Press Release, U.S. Sec. and Exch. Comm'n, SEC Charges Texas Man with Running Bitcoin-Denominated Ponzi Scheme (July 23, 2013), available at http://www.sec. gov/News/PressRelease/Detail/PressRelease/1370539730583\#.UgFSmmQ6XEg.

124. Id. 


\section{Lack of Trust}

Perhaps the most commonly identified obstacle for Bitcoin adoption is the problem of trust. Because the currency is not backed by any government or redeemable for any commodity, it may be difficult to convince individuals to trust a significant portion of their wealth to the virtual cryptocurrency. ${ }^{125}$ Defenders of Bitcoin frequently reply that, in their opinion, Bitcoin has at least as much intrinsic value as currencies that are controlled by opaque government agencies that are able to print money and inflate the currency according to their own rules. ${ }^{126}$ They point to the fact that there is a defined upper limit for the number of Bitcoins that can ever exist. ${ }^{127}$ In fact, supporters of Bitcoin argue that it is close to a "pure" currency: a currency that derives its value solely from its suitability as a currency. ${ }^{128}$

Additionally, history shows that a currency may not be doomed simply because it is neither backed by a government, nor redeemable for a commodity. The Iraqi Swiss Dinar, which had previously been the currency of Iraq and was imported from abroad, was abandoned by the Iraqi government following the first Gulf War when economic sanctions made future imports impossible. ${ }^{129}$ Despite this, the currency remained in circulation in the Kurdish north. ${ }^{130}$ Not only did the currency remain valuable, but after the 2003 U.S. invasion, a single Swiss Dinar was worth 150 of the new Dinars, which underwent hyperinflation under the monetary policies of the Saddam Hussein government. ${ }^{131}$

\section{ECONOMIC IMPLICATIONS OF BITCOIN}

Milton Friedman, the famous economist and Nobel Laureate, opposed the existence of the Federal Reserve and argued that a better system would entail a money supply steadily increasing at a predetermined rate. ${ }^{132}$ Although he almost certainly did not envision a virtual, decentralized system filling this role, Bitcoin does, and its economic implications are plentiful. For the purposes of this analysis, it

125. See Cyrus Sanati, Bitcoin Looks Primed for Money Laundering, CNN MONEY (Dec. 18, 2012, 2:49 PM), http://finance.fortune.cnn.com/2012/12/18/bitcoin-money-laundering/.

126. Kaplanov, supra note 21 , at 8.

127. Id.

128. Andresen, supra note 16.

129. Reuben Grinberg, Bitcoin: An Innovative Alternative Digital Currency, 4 HaSTINGS SCI. \& TECH. L.J. 159, 174 (2011).

130. Id.

131. Id. at $174-75$.

132. J.P. \& G.T., supra note 44. See also Brian Doherty, Best of Both Worlds, REASON, June 1995, available at http://reason.com/archives/1995/06/01/best-of-both-worlds. 
is assumed that no major disruption (whether governmental or otherwise) will occur sufficient to stop Bitcoin from continuing to develop and attract new consumers and merchants. In the absence of such a disruption, and because of the significant advantages that Bitcoin offers over traditional payment methods, it is likely to grow and stabilize over time.

\section{A. Transaction Costs}

In his seminal article, The Problem of Social Cost, Ronald Coase argued that where transaction costs are significant, they may lead to inefficient results if not controlled for. ${ }^{133}$ Coase included many costs in his analysis of social costs, ${ }^{134}$ but the cost that would most literally fit the definition is the actual cost of money changing hands. ${ }^{135}$ Coase accepted transaction costs as a given and proposed solutions for ensuring market efficiency despite transaction costs. ${ }^{136}$ Since Coase published his article in 1960, however, the technological revolution has enabled a reduction in many kinds of transaction costs. ${ }^{137}$ Transaction costs associated with Bitcoin are much lower than with traditional payment systems. ${ }^{138}$

Reducing transaction costs is almost always a positive development. ${ }^{139}$ Among the many benefits of reduced transaction costs are "direct cost savings, indirect benefits through improvements in agency costs, monitoring or coordination within existing organizations and markets, and even the creation of new types of market structures that are more efficient." ${ }^{140}$ There are, however, downsides to reduced

133. R. H. Coase, The Problem of Social Cost, 3 J.L. \& ECON. 1, 15-16 (1960).

134. The costs "to discover who it is that one wishes to deal with," "to conduct negotiations leading up to a bargain," "to draw up the contract," etc. Id. at 15.

135. See generally Pierre Schlag, The Problem of Transaction Costs, 62 S. CAL. L. REv. 1661 (1989), for an exploration of the difficulty of defining exactly what qualifies as a transaction cost.

136. See Coase, supra note 135 , passim.

137. See generally Luis Garicano \& Steven N. Kaplan, The Effects of Business-toBusiness E-Commerce on Transaction Costs, 49 J. INDUS. ECON. 463 (2001) (studying transactions costs arising from the introduction of the Internet in transactions between firms).

138. There is the cost (in energy and hardware) of mining as well as the transaction fees levied by exchanges. Bits and Bob: Bitcoin Has Got Geeks Excited. What About Economists?, ECONOMIST, June 16, 2011, available at http://www.economist.com/node/188 36780 [hereinafter Bits and Bob].

139. Bin Gu \& Lorin M. Hitt, Transaction Costs and Market Efficiency, 22 INT'L CoNF. INFO. SYS. PROC. 85, 85 (2001), available at http://opim.wharton.upenn.edu/ lhitt/tcme. pdf.

140. Id 
transaction costs; negative consequences can occur where lowered transaction costs lead to, or augment, a disparity in the knowledge of some participants in comparison to others. ${ }^{141}$

Online stock trading is a commonly used example of the consequences of lowered transaction costs. ${ }^{142}$ The arrival of the Internet made stock trading much cheaper, allowed for a proliferation of trading tools, fostered the growth of countless online brokerages, and created a boom in investing. ${ }^{143}$ At the same time, however, online investors were at a significant information disadvantage to professionals, and, as a result, they yielded lower returns. ${ }^{144} \mathrm{~A}$ similar future is easily imaginable for Bitcoin: lower transaction costs may draw more people into the market, create growth for merchants, and allow for new innovation in online financial services. At the same time, however, these new customers may well be uninformed of the risks and dangers of trusting their wealth to a virtual currency. Thus, there could be an increase in the number of people falling victim to fraud and digital theft. An additional concern that accompanies decreased transaction costs is the risk of losing the benefits that transaction costs may purchase. ${ }^{145}$ With Bitcoin compared to traditional payment processing options, the only benefit that is lost is institutional fraud protection; instead, the network and users share responsibility for preventing fraud. ${ }^{146}$

One potential benefit of Bitcoin's low transaction cost is the enablement of micropayments. In the past, it has been impractical to transfer small (i.e., less than one dollar) amounts of money due to the costs of individual transactions. ${ }^{147}$ Bitcoin makes such micropayments much more practical and therefore makes possible many transactions in the electronic sphere that previously had not been possible. ${ }^{148}$ This is particularly useful in the developing world where banking infrastructure is underdeveloped, and many do not have access to

141. Id.

142. Id. at 86 .

143. Id.

144. Id.

145. For example, in the case of traditional payment processing, transaction costs purchase ease and reliability for merchants, and fraud protection for consumers. See generally David M. Driesen \& Shubha Ghosh, The Functions of Transaction Costs: Rethinking Transaction Cost Minimization in a World of Friction, 47 ARIZ. L. REv. 61 (2005).

146. See supra Part I.

147. Dan Mitchell, In Online World, Pocket Change is Not Easily Spent, N.Y. TIMES (Aug. 27, 2007), http://www.nytimes.com/2007/08/27/technology/27micro.html.

148. See Grinberg, supra note 131, at 170. 
traditional banking services. ${ }^{149}$ In such places, electronic currencies such as Bitcoin offer opportunities previously unavailable.

Bitcoin not only has the potential to reduce transaction costs directly, but indirectly as well. The current structure of the credit card payment processing system suffers from inefficiencies not present with Bitcoin. Some credit cards, particularly rewards cards, charge merchants more transaction fees than standard cards. ${ }^{150}$ Merchants who accept credit cards are prohibited from discriminating between cards based on transaction fee amounts and from disclosing those fees to their customers. ${ }^{151}$ As a result, customers never internalize the cost of their choice in cards. ${ }^{152}$ This leads to inefficient behavior as customers choose cards that increase the transaction fee externalities. ${ }^{153}$ In contrast, Bitcoin has no prohibitive structure, so merchants are free to pass along any transaction costs they incur to consumers.

\section{B. Deflationary Spiral}

As the rate of new Bitcoin creation decreases, those who hold Bitcoins may choose to hold onto them rather than spend them in hopes of deflation. ${ }^{154}$ In its report, the European Central Bank (ECB) identified this as a likely possibility in the event that "the number of Bitcoin users starts growing exponentially for any reason, and assuming that the velocity of money does not increase proportionally." 155 Adding to this is the likelihood that some number of Bitcoins will simply be lost over time.156 In theory, this hoarding and loss would lead to "a depreciation of the prices of the goods and services quoted in Bitcoins." 157 But merchants, most of whom also accept other currencies,

149. Mindi Chahal, Is It the End of the Line for Cash?, MARKETING WK. (Nov. 29, 2012), http://www.marketingweek.co.uk/trends/is-it-the-end-of-the-line-for-cash/4004877.article.

150. See generally Adam J. Levitin, Priceless? The Economic Costs of Credit Card Merchant Restraints, 55 UCLA L. REV. 1321 (2008), for a discussion of these inefficiencies.

151. Id. at 1321.

152. Id.

153. Id. at 1388.

154. Bits and Bob, supra note 140.

155. EUROPEAN CENT. BANK, supra note 1, at 25.

156. Due to the anonymity of the system, in many instances, users may never be able to recover their coins if, for example, they lose a password or account number. For example, on the popular site Instawallet.org, if a user lost the URL to their wallet, there was no method for recovering it, as no identifying information was stored by the site. This problem became particularly burdensome when the site suffered an attack that forced the closing of the site. See Kim-Mai Cutler, Another Bitcoin Wallet Service, Instawallet, Suffers Attack, Shuts Down Until Further Notice, TeCHCRUNCH (Apr. 3, 2013), http:/l techcrunch.com/2013/04/03/bitcoin-instawallet/.

157. EUROPEAN CENT. BANK, supra note 1, at 25. 
could counter this. Merchants could simply peg the price of their goods and services to other currencies and accept Bitcoins at a fluctuating rate. 158

\section{The Absence of a Central Monetary Authority}

In the absence of any central authority, Bitcoins are created at a predetermined, knowable rate, and no self-interested individual or entity may change that. Quantitative easing and other mechanisms used by central banks are simply not possible. ${ }^{159} \mathrm{It}$ is this stability and predictability that attracts many to the system. ${ }^{160}$ Many individuals (sometimes referred to as "gold bugs"), who often do not trust central banks and the currencies that they back, ${ }^{161}$ prefer to store their wealth in commodities such as gold. ${ }^{162}$ It is not surprising then that the Libertarian Party has begun accepting donations in BTC. ${ }^{163}$ For many such individuals, Bitcoin represents an alternative, without the burden and risks of dealing in physical coins. ${ }^{164}$ The Bitcoin world is not without serious, respected players. In fact, the Winklevoss twins (of Facebook fame) hold one of the largest known Bitcoin fortunes. ${ }^{165}$

\section{GOVERNMENTS' INTEREST IN BITCOIN}

\section{A. Is Bitcoin Itself Illegal?}

Bitcoin operates in a legal grey area. As it is a new technology, and legislatures around the globe are not known for their quick action, there are very few laws currently on the books that specifically address virtual currencies such as Bitcoin. Thus, an analysis of the legal nature of Bitcoin must consider whether any existing laws might be applied to this new situation. This analysis is naturally speculative, and one cannot know for sure how judges might ultimately rule. Nonetheless, it is still possible to gain a general understanding of the legal environment

158. Id.

159. Bits and Bob, supra note 140 .

160. Id.

161. Grinberg, supra note 131, at 172-73.

162. Id.

163. Garance Franke-Ruta, The Libertarian Party Is Now Accepting Bitcoin Donations, ATLANTIC (Apr. 11, 2013), http://www.theatlantic.com/politics/archive/2013/04/the-liberta rian-party-is-now-accepting-bitcoin-donations/274935/.

164. Grinberg, supra note 131, at 172-73.

165. Nathaniel Popper \& Peter Lattman, Never Mind Facebook; Winklevoss Twins Rule in Digital Money, N.Y. TIMES DEALBOOK (Apr. 11, 2013, 3:11 PM), http://dealbook.nytimes .com/2013/04/11/as-big-investors-emerge-bitcoin-gets-ready-for-its-close-up/?hp\&_r=0. 
in which Bitcoin must be considered. In the United States, there is no shortage of laws regulating banks, currencies, securities, and money laundering. Taking each unique area in turn, no U.S. law currently on the books explicitly applies to Bitcoin. However, regulators have already made efforts to bring Bitcoin within the existing legal framework.

\section{Regulation of Currencies}

Bitcoin is widely understood to be a form of currency that is original and unique from those that have come before. In fact, a U.S. district court has now ruled that Bitcoin is a currency. ${ }^{166} \mathrm{As}$ a result, this is where any legal analysis must begin. The U.S. Constitution gives to Congress the exclusive right to "coin Money, regulate the Value thereof, and ... To provide for the Punishment of counterfeiting the Securities and current Coin of the United States."167 However, this does not prohibit the issuance of private community currencies (i.e., currencies intended to circulate amongst a specific network of people or community).168 The strongest argument is that Bitcoin is most analogous to such community currencies, and, thus, it is not likely to be held to be in violation of Congress' constitutionally granted currency monopoly.169 Additionally, in the discussion of Bitcoin's legality, the Stamp Payments Act of 1862, which prohibits the use of a token, note, or check worth less than one dollar, ${ }^{170}$ is often mentioned. ${ }^{171}$ However, as it currently exists in only digital form, ${ }^{172}$ Bitcoin most likely does not fall within the scope and purpose of the Act as read by the Supreme Court. ${ }^{173}$

166. Sec. \& Exch. Comm'n v. Shavers, No. 4:13-CV-416 (E.D. Tex. 2013), available at http://www.lawfareblog.com/wp-content/uploads/2013/10/SEC-v.-Bitcoin-Savings-and-

Trust.pdf.

167. U.S. ConST. art. I, $\S 8$.

168. Barbara A. Good, Economic Commentary, Private Money: Everything Old is New Again, FED. Reserve BANK of Cleveland (Apr. 1, 1998), available at http://www.cleve landfed.org/research/commentary/1998/0401.pdf ("Private money is not prohibited if it complies with certain government regulations.").

169. See Kaplanov, supra note 21 , at 24.

170. Quenton Narcisse, The Unexpected Weapon Against Bitcoin: The Stamp Payments Act of 1862, COMPLEX NETwORK (Jan. 8, 2014), http://www.complex.com/tech/2014/01/bit coin-stamp-payments-act-1862.

171. See Grinberg, supra note 131, at 183-91; Kaplanov, supra note 21, at 39 n.332.

172. There are various endeavors to create physical embodiments of Bitcoins. The most known of these is BitBills, which can be found at http://www.bitbills.com/. These endeavors require a separate legal analysis outside the scope of this paper, and likely may be illegal under existing law in many countries.

173. Grinberg, supra note 131, at 187 (analyzing the court's ruling in United States v. Van Auken, 96 U.S. 366 (1878)). 
Some who disagree with the preceding conclusions have pointed to the U.S. government's prosecution of the creator of the Liberty Dollar in arguing that the government might view Bitcoin as an illegal currency. ${ }^{174}$ The Liberty Dollar was a physical currency printed and distributed by Bernard von NotHaus in the late 1990s and early $2000 \mathrm{~s} .{ }^{175}$ By backing his currency in gold, silver, and other precious metals, NotHaus sought to create an inflation-proof currency to compete with the U.S. Dollar. ${ }^{176}$ The statutes under which NotHaus was prosecuted cannot be said to apply to Bitcoin. ${ }^{177}$ Further, the government's actions against NotHaus are best characterized as prosecution of counterfeiting and fraud rather than the creation of a unique currency. ${ }^{178}$

Other Bitcoin detractors point to the ill-fated business, E-Gold, which allowed individuals to trade digital gold ownership. ${ }^{179}$ The U.S. Code makes it illegal to operate an unlicensed money transmitting business. ${ }^{180}$ It was for this crime, and money laundering, that the operators of E-Gold pled guilty to charges in July 2008.181 Because the company failed to register as a money transmitting business and implement required oversight procedures, the company became a favorite tool of criminals looking to launder illegally gained proceeds. ${ }^{182}$ At no time did the government argue that E-Gold itself, as a digital currency, was illegal in any way, but instead argued that the company was required to have obtained a license. ${ }^{183}$ It is important to note that these charges did not shut down E-Gold. Rather, the government required that the company "move to fully comply with all applicable federal and state laws relating to operating as a licensed money

174. See United States v. von NotHaus, No: 5:09-CR-27-V (W.D.N.C. Mar. 18, 2011) (jury verdict).

175. Grinberg, supra note 131, at 191.

176. Id.

177. 18 U.S.C. $\S \S 485-486$ only apply to physical currency that resembles official currency. Therefore, they are simply not applicable to Bitcoin. Grinberg, supra note 131, at 192.

178. The Department of Justice referred to NotHaus as a "domestic terrorist" and argued that he encouraged Liberty Dollar users to inject the currency into regular circulation, thus profiting from the transaction due to the face value being higher than the cost to produce. This is essentially the business model of any ordinary counterfeiter. See Grinberg, supra note 131, at 191-93.

179. E-gold, WIKIPEDIA, http://en.wikipedia.org/wiki/E-gold (last visited Aug. 6, 2013).

180. 18 U.S.C. $\$ 1960$ (2012).

181. Press Release, U.S. Dep't of Justice, Digital Currency Business E-Gold Pleads Guilty to Money Laundering and Illegal Money Transmitting Charges (July 21, 2008), available at $\mathrm{http}: / / \mathrm{www}$.justice.gov/opa/pr/2008/July/08-crm-635.html.

182. Id.

183. See id. 
transmitting business and the prevention of money laundering." 184 The prosecution of the operators of E-Gold appears to be very similar to the recent arrest and prosecution of Bitcoin advocate Charlie Shrem for money laundering. 185

Finally, even if one were to conclude that the "printing" of Bitcoins violates U.S. law-or, for that matter, any country's law-there is the difficulty of deciding whom to punish. It is not obvious who should even be said to be responsible for the creation of new Bitcoins. One might argue that miners produce new coins, but the stronger argument is that the network itself rewards miners for their actions with new Bitcoins. One cannot drag a distributed network, which exists both everywhere and nowhere all over the globe, into a courtroom.

\section{Securities Regulation}

Perhaps the area of finance most heavily regulated in the United States is that of securities. Despite the plethora of laws and regulations, Bitcoins are unlikely to be regulated as securities for many reasons. To begin, they do not fit the definition of a security. ${ }^{186}$ Securities are defined as "any note, stock, . . . transferable share, [or] investment contract."187 Put simply, Bitcoin does not fall into any of these categories. ${ }^{188}$ Additionally, currencies are expressly excluded from existing securities laws. 189 Nonetheless, the growing number of investment opportunities that are available to Bitcoin users almost certainly would qualify as securities. ${ }^{190}$ For that reason, the proprietors of such websites and businesses will almost certainly be held responsible for abiding by the laws of their home countries, wherever that may be. ${ }^{191}$ In fact, the SEC has already demonstrated a willingness to charge those who defraud Bitcoin investors under existing securities

184. Id.

185. See generally The Coin Prince, THE VERGE (Feb. 4, 2014), http://www.theverge .com/2014/2/4/5374172/the-coin-prince-charlie-shrem-bitinstant-bitcoin-money-launderingscandal (detailing the downfall of Charlie Shrem, a leading Bitcoin voice who was recently arrested and charged with crimes relating to money laundering).

186. See Grinberg, supra note 131, at 195.

187. 15 U.S.C. $\S 77 \mathrm{~b}(\mathrm{a})(1)(2012)$.

188. See Grinberg, supra note 131, at 194-99.

189. Id. at 200-04 (citing Procter \& Gamble Co. v. Bankers Trust Co., 925 F. Supp. 1270 (S.D. Ohio 1996)).

190. See Bitcoin Derivatives Market and Exchange, ICBIT BITCOIN EXCHANGE, http://icbit.se (last visited Oct. 19, 2013), for an example of an active Bitcoin derivatives market and exchange.

191. In fact, this is already taking place. Bitcoin-Central, a Bitcoin exchange, has registered in France, as discussed infra Part III.D. 
regulations. ${ }^{192}$ In that case, a Texas federal judge ruled that investments in Bitcoins qualified as securities. ${ }^{193}$

\section{B. Illegal Activity Conducted in Bitcoin}

There are many reasons why governments might want to take notice of an unregulated, virtual, and anonymous currency. Beyond the risk that one's citizens may fall victim to scammers and Ponzi schemers, Bitcoin offers significant opportunities for those who would launder money, hide income from tax authorities, or transact in illicit goods. ${ }^{194}$ Additionally, in countries where the ruling regimes exert heavy-handed control of the Internet (e.g., China, Saudia Arabia, United Arab Emirates), Bitcoin offers outlaw bloggers and revolutionaries the ability to pay for services, such as web publishing, without having to reveal their identities.

\section{Money Laundering and Tax Fraud}

The relative anonymity of Bitcoin transactions, and the speed and ease with which they can be carried out, makes the currency particularly attractive for money laundering. ${ }^{195}$ As an example, the aptly named BitLaundry website is explicitly dedicated to the laundering of Bitcoins (in exchange for a fee, of course). ${ }^{196}$ Additionally, the Silk Road, a site for purchasing illegal drugs, ${ }^{197}$ automatically mixed

192. See generally Press Release, supra note 125 (outlining charges against Trendon T. Shavers).

193. Jordan Maglich, Court Green-Lights Bitcoin Lawsuit; Rules Investments Constitute 'Securities,' ForBes (Aug. 7, 2013), http://www.forbes.com/sites/jordanmaglich/2013/08/07/ court-green-lights-bitcoin-lawsuit-rules-investments-constitute-securities/.

194. See Intelligence Assessment, Fed. Bureau of Investigation, Bitcoin Virtual Currency: Unique Features Present Distinct Challenges for Deterring Illicit Activity (Apr. 24, 2012), available at http://www.wired.com/images_blogs/threatlevel/2012/05/BitcoinFBI.pdf [hereinafter FBI Intelligence Assessment].

195. See generally Robert Stokes, Anti-Money Laundering Regulation and Emerging Payment Technologies, 32 Banking \& Fin. SERVICEs Pol'y ReP. 1 (2013), and Danton Bryans, Note, Bitcoin and Money Laundering: Mining for an Effective Solution, 89 IND. L.J. 441 (2014), for a more thorough analysis of the money laundering risks associated with virtual currencies.

196. BitLaundry, and more information on its function and purposes, may be found at http://app.bitlaundry.com/. Additionally, there are a variety of Bitcoin "mixers" or "tumblers" that serve essentially the same purpose.

197. See discussion infra Part III.B.2. 
funds being deposited before putting them into a user's account. ${ }^{198}$ According to the site's operator, this made it practically impossible to link a specific user's outside Bitcoin wallet to a Silk Road transaction. ${ }^{199}$

The same features that make Bitcoin attractive to money launderers also make it attractive to those who would prefer not to pay taxes and are willing to break the law to avoid doing so. ${ }^{200}$ Though it is unclear how Bitcoin will be taxed, ${ }^{201}$ the anonymity of the Bitcoin system makes efficient enforcement highly impractical. For this reason, there is significant concern that Bitcoin could become a major tax haven. ${ }^{202}$

\section{Silk Road And Similar Marketplaces}

Perhaps the most visible example of why world governments are likely to take a greater interest in Bitcoin was the, now defunct, online marketplace known as Silk Road and the way in which it facilitated the trade in illegal drugs. ${ }^{203}$ In June 2011, the online magazine Gawker published an article that revealed the existence of the marketplace to the general (or at least the Gawker reading) public. ${ }^{204}$ This set off a media flurry and caused outrage among concerned members of society. ${ }^{205}$

Silk Road was an online marketplace where one could purchase, among other things, ${ }^{206}$ any of 340 different illegal drugs from individual

198. See Andy Greenberg, Follow the Bitcoins, FoRBES, September 5, 2013, http://www. forbes.com/sites/andygreenberg/2013/09/05/follow-the-bitcoins-how-we-got-busted-buyingdrugs-on-silk-roads-black-market/.

199. See id.

200. Omri Marian, Are Cryptocurrencies Super Tax Havens?, 112 MICH. L. REv. (forthcoming 2013).

201. See Catherine Hollander, How is Bitcoin Taxed? The IRS Doesn't Know, NATIONAL JOURNAL, Jan. 26, 2014, http://www.nationaljournal.com/economy/how-is-bitcoin-taxed-the -irs-doesn-t-know-20140126.

202. Marian, supra note 202.

203. Because Silk Road operates only on the "dark web," there is no accessible URL at which it may be accessed outside of the anonymous TOR network. However, more information and background on the Silk Road may be found at http://en.wikipedia.org /wiki/Silk_Road_(marketplace).

204. See Adrian Chen, The Underground Website Where You Can Buy Any Drug Imaginable, GAWKER (June 1, 2011, 4:20 PM), http://gawker.com/the-underground-website -where-you-can-buy-any-drug-imag-30818160.

205. See Brett Wolf, Senators Seek Crackdown on "Bitcoin" Currency, REUTERS, June 8, 2011, http:/www.reuters.com/article/2011/06/08/us-financial-bitcoins-idUSTRE7573T3201 10608.

206. Chen, supra note 206 (explaining that the site's terms of service prohibit "anything who's [sic] purpose is to harm or defraud, such as stolen credit cards, assassinations, and weapons of mass destruction"). 
sellers. ${ }^{207}$ Your purchase would then be mailed straight to your doorstep from wherever in the world the seller happened to be located. ${ }^{208}$ The site had sections for reviews-much like Amazon or other online retailersand many sellers even offered free samples. ${ }^{209}$ The network relied heavily on the reputations of its sellers and worked hard to eradicate scammers. ${ }^{210}$ Similar to many other legitimate online marketplaces, buyers were able to gauge whether to trust a specific seller based on the experiences of others. ${ }^{211}$

The secret to Silk Road's existence was its perceived anonymity; both buyers and sellers were unidentifiable (through the site itself), and the site lived in a dark, supposedly untraceable corner of the Internet. ${ }^{212}$ This anonymity was accomplished via the utilization of two technologies: 1) an online network known as TOR and 2) Bitcoin. ${ }^{213}$ To oversimplify things for the sake of clarity, TOR made it impossible to track a Silk Road user on the site by monitoring internet traffic, and, because payments were only accepted in anonymous Bitcoins, users could not be tracked that way either. ${ }^{214}$ Governments were thought to be completely blind to what their citizens purchased in the marketplace and even to the fact that the markets were there to begin with.

On October 1, 2013, the FBI announced that it had successfully shutdown Silk Road. ${ }^{215}$ Rather than some weakness in the TOR or Bitcoin systems, the FBI simply used old-fashioned police techniques to track down the site's operator, who turned out to be somewhat less of an evil genius than internet lore had built him up to be. ${ }^{216}$ By intercepting drug shipments and then exploring the digital trails and communications of those who fell into their grasp, the FBI was able to

207. Id.; Cole Stryker, Navigating the Deep, Dark Web, TECHDIRT (Oct. 30, 2012, 2:56 PM), http://www.techdirt.com/articles/20121030/01363220883/navigating-deep-dark-web.s html.

208. See Chen, supra note 200.

209. Id.

210. Id.

211. Id.

212. Id.

213. For more information on TOR, see generally Joel Falconer, Mail-Order Drugs, Hitmen \& Child Porn: A Journey into the Dark Corners of the Deep Web, NEXT WEB (Oct. 8, 2012, 2:56 AM), http://thenextweb.com/insider/2012/10/08/mail-order-drugs-hitmen-chil d-porn-a-journey-into-the-dark-corners-of-the-deep-web/, for a more detailed exploration of TOR beyond the scope of this paper.

214. Chen, supra note 200.

215. Adrian Jeffries, FBI seizes underground drug market Silk Road, owner indicted in New York, THE VERGE (Oct. 2, 2013), http://www.theverge.com/2013/10/2/4794780/fbi-seiz es-underground-drug-market-silk-road-owner-indicted-in-new.

216. See Kim Zetter, How the Feds Took Down the Silk Road Drug Wonderland, WIRED (Nov. 18, 2013), http:/www.wired.com/threatlevel/2013/11/silk-road/. 
quietly piece together an understanding of the sellers and administrators who made up the marketplace. 217 Ultimately, an undercover agent was able to develop a relationship with Dread Pirate Roberts (DPR), the pseudonymous owner behind Silk Road.218 Ultimately, sloppy efforts at hiding his identity allowed the FBI to unmask DPR, who was revealed to be Ross Ulbricht, a 29-year-old from San Francisco. ${ }^{219}$

However, the value of Bitcoins to those who wish to conduct illegal activity anonymously was not limited to Silk Road. There are sites that offer firearms, scrubbed of their serial numbers, for sale to anonymous buyers. ${ }^{220}$ Similar marketplaces could be created to foster the sale of any type of goods, legal or not. Already, successors to Silk Road have begun to emerge. 221

\section{Use of Bitcoins by and in Subversion of Oppressive Governments}

Bitcoins are also very attractive to citizens and governments of sanctioned nations. For citizens of countries where the currency is relatively stable, Bitcoin's volatility presently makes transfer of a significant portion of one's wealth unattractive. However, in places where the government currency is equally as risky and unstable, Bitcoin is increasingly an attractive option. For example, in Iran, citizens who would like to protect their wealth against hyperinflation by converting it into another currency previously relied on the U.S Dollar, but that has become increasingly difficult due to international banking sanctions. ${ }^{222}$ In response, a growing number of Iranians are now moving their money into Bitcoins, thanks to the ability to do so anonymously and electronically. ${ }^{223}$ In fact, this phenomenon is not limited to the citizenry of sanctioned governments.

In March 2013, when the Cypriot President announced a plan to take a portion of the savings accounts held in Cypriot banks, depositors in Cyprus and other financially troubled European countries

217. See id.

218. See id.

219. See id.

220. Gerry Smith, How Bitcoin Sales of Guns Could Undermine New Rules, HUFFINGTON POST (Apr. 15, 2013, 7:30 AM), http://www.huffingtonpost.com/2013/04/15/bit coin-guns_n_3070828.html.

221. Adrian Jeffries, After Silk Road's Demise, Online Drug Dealing Moves to New Sites, THE VERGE (Oct. 4, 2013), http://www.theverge.com/2013/10/4/4799770/drug-dealers-setup-mini-silk-roads-after-federal-bust.

222. Sanati, supra note 127.

223. Id. 
panicked. ${ }^{224}$ Two days later, the price of Bitcoins began to rise drastically, and Internet search engines showed a significantly increased interest in the virtual currency. ${ }^{225} \mathrm{It}$ is widely believed in the financial community that these events were linked. ${ }^{226}$ If that is the case, it means that a significant number of citizens of established, unsanctioned countries have made the decision that a virtual currency in its infancy is more trustworthy than the currency issued by their central banks and backed by their governments.

Additionally, dissidents in oppressive countries may find Bitcoin to be a preferred method of payment for their opposition activities. For example, an anti-government blogger in China must take great care to avoid being identified by the highly skilled Internet police. ${ }^{227}$ One weak link in the chain has traditionally been the problem of payment: How do you pay the publisher of your blog for his services when financial transactions can be tracked?228 Now that the largest web publisher, WordPress, will be accepting payment in BTC, the threat of detection is lessened significantly. ${ }^{229}$

The previous examples identify ways in which individuals might protect their wealth and their anonymity. Bitcoin presents a third alternative in these countries: sanctioned nations might transact in BTC to circumvent international regulations. For example, the Iranian government could theoretically sell its oil to unscrupulous buyers and accept payment in BTC to avoid the eyes and punishment of the United States and its allies. ${ }^{230}$

\section{Government Responses Thus Far}

As Bitcoins become more valuable and achieve more publicity, Governments are beginning to take notice. Already, U.S. Senators have voiced concern over the illegal substances being purchased online in Bitcoins; an internal FBI report regarding Bitcoins was leaked on the internet; the ECB published a paper evaluating virtual currency schemes including Bitcoin; and the Chinese government banned the use of Bitcoin by financial institutions.

224. Maria Bustillos, The Bitcoin Boom, NEw YORKER (Apr. 2, 2013), http://www.new yorker.com/online/blogs/elements/2013/04/the-future-of-bitcoin.html.

225. Id.

226. $I d$.

227. See generally Internet Censorship in China, N.Y. TIMES, http://topics.nytimes.com/ topics/news/international/countriesandterritories/china/internet_censorship/index.html (last visited Aug. 6, 2013).

228. Allison, supra note 91.

229. Id.

230. See Sanati, supra note 127. 


\section{Response in the United States}

In response to a widely circulated article about the Silk Road, ${ }^{231}$ Senators Charles Schumer and Joe Manchin wrote a letter to the United States Attorney General, Eric Holder, to urge him and the Drug Enforcement Administration (DEA) to "take immediate action and shut down the Silk Road network."232 Though the Senators did not suggest a manner in which this might be done, they did point out the multitude of technical difficulties in doing so, one of which was the site's exclusive use of BTC for payment. ${ }^{233}$ The letter prompted the DEA to respond that it is also concerned about the potential for illegal activity offered by Bitcoin, is "well aware of these emerging threats," and "will act accordingly." 234

In a leaked report, the United States Federal Bureau of Investigation (FBI) concluded that Bitcoin is currently being used and accepted by both legitimate and criminal businesses and users. ${ }^{235}$ The report found that, because of the lack of a central, controlling entity, the Bitcoin network is incapable of regulating, monitoring, or reporting on the activity of users who violate the law. ${ }^{236}$ The FBI did, however, point out that Bitcoin transaction anonymity can be overcome in many cases where users have not taken additional steps to hide their identities, such as masking their IP address and laundering their Bitcoins. ${ }^{237}$ Users are particularly vulnerable when converting Bitcoins into fiat currency. ${ }^{238}$ Finally, the FBI report concluded that many of the thirdparty Bitcoin exchanges and businesses qualify as money transmitters under existing international standards; and, therefore, must register, implement anti-money laundering programs, collect certain information, and report suspected money launderers. ${ }^{239}$

Finally, regulatory bodies have begun to take an interest in Bitcoin. In the first clear example of bureaucratic ineptitude regarding Bitcoin, California's Department of Financial Institutions issued a cease and desist letter to the Bitcoin Foundation alleging that the Foundation is

231. See Chen, supra note 200.

232. Letter from Charles E. Schumer \& Joe Manchin, U.S. Senators, to Eric Holder, Att'y Gen. of the U.S. \& Michele Leonhart, Adm'r of the Drug Enforcement Admin. (June 6, 2011), available at http://manchin.senate.gov/public/index.cfm/2011/6/manchin-urgesfederal-law-enforcement-to-shut-down-online-black-market-for-illegal-drugs.

233. See id.; Wolf, supra note 207.

234. Wolf, supra note 207.

235. FBI Intelligence Assessment, supra note 196.

236. Id.

237. Id.

238. Id.

239. Id. 
engaged in unlawful money transmission. ${ }^{240}$ Unfortunately, it appears that the State of California is unaware that the Foundation is nothing more than a nonprofit organization dedicated to the promulgation of best practices for the Bitcoin environment, and they are not engaged in the sale or transfer of Bitcoins. ${ }^{241}$ The Foundation made this clear in its response to the Department. ${ }^{242}$ Further, the Foundation stated its belief that even if it was engaged in the sale of Bitcoins, the sale of Bitcoins is not an activity over which the Department has jurisdiction. ${ }^{243}$

The SEC has issued an investor report warning about the risk of Bitcoin-related Ponzi schemes. ${ }^{244}$ The New York Department of Financial Services has taken an interest in the report, subpoenaing Bitcoin-related businesses in an effort to investigate, among other things, their utilization of anti-money-laundering programs and consumer protection measures. ${ }^{245}$ Rather than an attempt to stop the development of virtual currencies, the Department has expressed a desire to put in safeguards that "will be beneficial to the long-term strength of the virtual-currency industry." 246

\section{Response Abroad ${ }^{247}$}

In light of the emergence of virtual currencies, the ECB, sought to classify such currencies, and evaluate their impact. ${ }^{248}$ The ECB report defined virtual currency as "a type of unregulated, digital money, which is issued and usually controlled by its developers, and used and accepted among the members of a specific virtual community."249 Such

240. See Jon Matonis, Bitcoin Foundation Receives Cease and Desist Order from California, FoRBEs (June 23, 2013, 11:11 AM), http://www.forbes.com/sites/jonmatonis/20 13/06/23/bitcoin-foundation-receives-cease-and-desist-order-from-california/.

241. See id.

242. Letter from J. Dax Hansen, Partner, Perkins Coie, LLP, to Tara L. Murphy, Assistant Gen. Counsel, Cal. Dep't of Fin. Insts. (July 1, 2013), available at http:/www. scribd.com/doc/151346841/Bitcoin-Foundation-Response-to-California-DFI.

243. Id.

244. U.S. SEC. AND EXCH. COMM'N, Investor ALERT: PonZI Schemes USING VIRTUAL CURRENCIES (2013), available at http://www,sec.gov/investor/alerts/ia_virtualcurrencies, pdf.

245. Robin Sidel, Regulator Examines Bitcoin Practices, WALL ST. J. (Aug. 11, 2013, 10:11 PM), http://online.wsj.com/news/articles/SB1000142412788732358560457900688014 3449754 .

246. Id.

247. For a thorough survey of the legality of Bitcoin in forty foreign jurisdictions and the European Union, see LaW LiBraRy of Cong., LL File No. 2014-010233, Regulation of BITCOIN IN SELECTED JURISDICTIONS (2014).

248. EUROPEAN CENT. BANK, supra note 1, at 5.

249. Id. at 13 . 
currencies were then split into three categories: closed schemes, where currencies are limited only to a particular environment;250 unidirectional schemes, where currencies can be purchased with traditional currencies, but cannot be "cashed out";251 and bidirectional schemes like Bitcoin, which operate most similarly to traditional currencies and can be exchanged in either direction. ${ }^{252}$

The ECB identified many problems that affect virtual currencies: credit, liquidity, and operational risk (i.e., risk of disruptions to the network or underlying system); legal uncertainty; fraud risk; and a lack of regulation and oversight. ${ }^{253}$ The goal of the report was to evaluate the threat that these problems pose to the central bank's tasks of protecting price stability, financial stability, and payment system stability. ${ }^{254}$ The report concluded that, because virtual currencies are created outside of the regulation of central banks, they have the potential-as yet unrealized-to lessen the effectiveness of central banks' attempts to control money and credit developments. 255 However, the authors concluded that, due to the relatively small amount of transactions, virtual currencies do not currently pose a risk to price, financial, or payment system stability. 256 The ECB report identified an additional reason why central banks need to take further stock of virtual currencies and their potential effects: the risk of negative effects on the reputations of central banks if incidents regarding virtual currencies are interpreted as the central banks having failed to adequately do their jobs. 257

One of the ECB's ultimate conclusions was that, because they share similar characteristics to traditional payment systems and because of their potential impacts, virtual currencies like Bitcoin fall within the responsibility of the world's central banks to assess. ${ }^{258}$ Admitting that their assessment was highly dependent on virtual currencies presently having very low adoption, the ECB report concluded that periodic reexamination of the issue would be necessary. ${ }^{259}$

In China, the government has prohibited banks and payment institutions from dealing in Bitcoins. ${ }^{260}$ The government has further

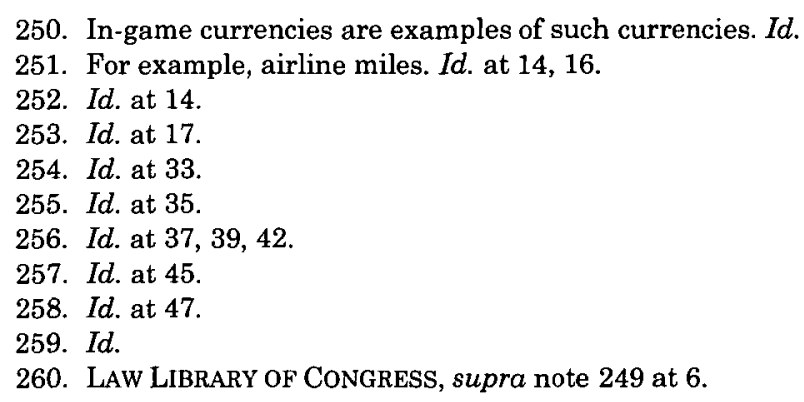


warned that Bitcoin is not a currency and should not be circulated or used as such. ${ }^{261}$ Warning of potential money laundering risks of the Bitcoin system, the Chinese government has further strengthened the oversight of websites involved with Bitcoin. ${ }^{262}$

\section{Ongoing and Future Government Action}

One of the suggestions of the ECB was that virtual currency scheme owners be required to register as financial institutions in their respective jurisdictions to allow for oversight and regulation. ${ }^{263}$ Though this might be an effective approach to some schemes, in the case of Bitcoin, there is no central owner that could be so compelled. The ECB even admitted "governments and central banks would face serious difficulties if they tried to control or ban any virtual currency scheme." ${ }^{64}$ Any such attempt would be severely hampered by the lack of geographical boundaries. ${ }^{265}$ In the specific case of Bitcoin, "there is not even a central point of access, i.e. there is no server that could be shut down if the authorities deemed it necessary." ${ }^{266}$ This is not to say that entities operating within the Bitcoin sphere could not be regulated as the FBI suggested in their report. 267

The simplest and most likely route by which regulation will be introduced to the Bitcoin network is through the regulation of the exchanges, trading floors, and other financial entities developing around Bitcoin. In France, a partnership between a payment services provider, Aqoba, and Paymium, the company behind Bitcoin-Central, ${ }^{268}$ allows users to engage in the exchange of Bitcoins within the European regulatory framework (client funds are protected by the "Garantie des dépôts" mechanism, similar to the Federal Deposit Insurance Corporation). ${ }^{269}$ Perhaps indicating an openness to some amount of regulation, one exchange's terms of service prohibited any illegal use of the website, and its policy was to require identification information for

\footnotetext{
261. Id.

262. Id.

263. EUROPEAN CENT. BANK, supra note 1, at 44.

264. Id. at 42.

265. See id. at 47 .

266. Id. at 43.

267. See FBI Intelligence Assessment, supra note 196.

268. Bitcoin-Central is both an exchange and a trading platform where users can buy, sell, and store Bitcoins, and can be found at http://www.bitcoin-central.net.

269. Bitcoin-Central.net: Important Informations Regarding Our Partnership with Aqoba, BITCOIN FORUM (Dec. 8, 2012, 5:06 PM), https://www.bitcoinforum.com/bitcoinnews-press-hits-notable-sources-gossips-scandals/bitcoin-central-net-important-informatio ns-regarding-our-partnership-with-aqobal.
} 
any accounts whose activity might have indicated money laundering or other illegal activity. ${ }^{270}$ This was a purely voluntary action on the exchange's part, and it did not specify what tools it used to identify such activity; however, the exchange stated a willingness to work with and even freeze accounts at the request of any "competent authority investigating a fraud or any other illegal activity."271

This regulation of Bitcoin service providers appears to be the chosen course of action in the United States as well. In March 2013, the Department of the Treasury Financial Crimes Enforcement Network (FinCEN) issued guidance on virtual currencies, 272 of which Bitcoin is the most prominent. The guidance says that ordinary users of virtual currencies are not subject to regulation, just as ordinary users of cash are not. ${ }^{273}$ However, exchanges and miners who sell their Bitcoins are defined as money services businesses, and both are subject to regulation as money transmitters. ${ }^{274}$ Exchanges are subject to the same regulations as ordinary currency exchanges. 275 Already, the U.S. government has demonstrated a willingness to prosecute those who fail to adhere to anti-money laundering laws. 276

There are, however, additional signs that some factions of the U.S. government may be taking a more aggressive approach to Bitcoin. In May 2013, the Department of Homeland Security seized the funds of Mt. Gox held by Dwolla, a payment network used by many people to transfer money to their Mt. Gox accounts. ${ }^{277}$

270. Terms of Use, MT. Gox, https://mtgox.com/terms_of_service (last updated Jan. 20, 2012).

271. Id

272. See Memorandum from the Dep't of the Treasury Fin. Crimes Enforcement Network on the Application of FinCEN's Regulations to Persons Administering, Exchanging, or Using Virtual Currencies (Mar. 18, 2013), available at http://www.fincen. gov/statutes_regs/guidance/pdf/FIN-2013-G001.pdf [hereinafter Treasury Memorandum].

273. See id.

274. Id.; see also Jeffrey Sparshott, Regulator on Bitcoin: Same Rules Apply, WALL STREET JOURNAL (Aug. 26, 2013), http://online.wsj.com/news/articles/SB100014241278873 23407104579037301852662422.

275. Id.

276. The Coin Prince, supra note 187 (detailing the downfall of Charlie Shrem, a leading Bitcoin voice who was recently arrested and charged with crimes relating to money laundering).

277. Max Ehrenfreund, Homeland Security's Move Against Bitcoin on Mt. Gox Could Foreshadow Closer Regulation, WASH. POST (May 15, 2013), http://articles.washingtonpost .com/2013-05-15/business/39274717_1_money-laundering-monetary-policy-currency. 


\section{ANALYSIS}

As time passes, the future of Bitcoin seems increasingly likely to be one of growth. Despite the crash that occurred in June of 2011,278 the price has now rebounded strongly. ${ }^{279}$ Though future heists may again erode users' trust, the system has proven its ability to handle such events and rebound in a relatively short amount of time. That being said, if Bitcoin does continue to grow in popularity and value, the incentives for hackers to profit by theft and fraud will only increase. Thus, the possibility of a trust-destroying, catastrophic event cannot be ruled out.

Because the current legal framework does not provide any clear justification for a government to attempt to shutdown the entire Bitcoin system, this is unlikely.280 Even if a government did decide to outlaw Bitcoin, no entity has presently demonstrated that it has the ability to shutdown Bitcoin. The decentralized nature of the network makes any direct attack nearly impossible, and, thanks to the relative anonymity of the system, identifying individual users to prosecute in areas where Bitcoin is, or could become, illegal would be incredibly labor intensive and likely not worth the benefit of taking down small-time consumers on a large scale. That being said, targeting only the largest users of illegal operations such as Silk Road is feasible and a likely choice for interested governments. ${ }^{281}$

Absent a successful attempt by world governments to impede or stop the growth of Bitcoin, it is expected to continue to grow. 282 The amount of money moving through the network is not insignificant. At one point, it was noted that for every Bitcoin in existence, 1.4 were being moved around the network in a single day. ${ }^{283}$ The startup investors at $\mathrm{Y}$ Combinator certainly thought that was significant when they invested in Coinbase, a hosted Bitcoin wallet that describes itself as the "PayPal of Bitcoin." 284

In many parts of the developing world, access to banking services is very limited, but mobile networks are spreading rapidly. ${ }^{285}$ As a result, Bitcoin and other similar systems offer significant potential as a low-

278. EUROPEAN CENT. BANK, supra note 1 , at 38.

279. Current price is $\$ 182.82$ as of October 20 , 2013. MT.Gox, http://mtgox.com (last visited Oct. 20,2013 ).

280. Of course, nothing would prevent a legislative body from choosing to write new laws making Bitcoin illegal.

281. See FBI Intelligence Assessment, supra note 196.

282. See EUROPEAN CENT. BANK, supra note 1, at 47.

283. Falconer, supra note 84.

284. Id.

285. Chahal, supra note 151. 
cost way to store wealth, make payments, and send money around the world. ${ }^{286}$ Additionally, because Bitcoins can be divided to eight decimal places, in conjunction with the lack of transaction fees, micropayments can be transmitted in amounts previously not possible before Bitcoin. ${ }^{287}$ These features make Bitcoin a potentially useful tool for users in the developing world.

There are many economic benefits to Bitcoin. By significantly reducing transaction costs, the velocity of money may be improved, micropayments become possible, and individuals in developing nations gain access to banking services they would not otherwise be able to obtain. Further, the creation of a truly global, virtual currency opens the door to an unknowable amount of future innovation. Already, individuals are dreaming up new manners of investing, banking, and doing business in BTC. 288

The most likely, and wisest approach that governments might take to Bitcoin is to attempt to regulate the transactions that take place in BTC, rather than the system itself. It seems clear that Bitcoin exchanges, and other similar entities, will find themselves held to the same regulations as commodities exchanges. ${ }^{289}$ Given the potential benefits of a regulated Bitcoin network, it would be a mistake for governments to take a more hostile approach to the system itself.

\section{CONCLUSION}

In light of the preceding analysis, governments should not attempt to outlaw or stop Bitcoin for three reasons: 1) Bitcoin is not presently illegal under existing legal frameworks in nearly every country; 2) Bitcoin offers significant economic advantages over traditional currencies and payment methods; and 3) governments do not currently possess the ability to target the Bitcoin network directly.

To suggest that governments should not try to outlaw Bitcoin is not an argument against regulation. Just as banks, which deal in traditional currencies, are regulated in all the developed countries around the world, those who hold deposits, facilitate trades, and process payments in BTC are potentially open to the regulation of their home governments. Though new legislation will likely be needed to

286. Andresen, supra note 16.

287. Grinberg, supra note 131 , at 163,170 .

288. One innovator even plans to conduct a Bitcoin IPO to generate funding for his planned Bitcoin exchange. Adrianne Jeffries, Tel Aviv Techie Attempts the First 'Bitcoin IPO,' BETABEAT (July 25, 2011, 4:01 PM), http://betabeat.com/2011/07/tel-avivtechie-attempts-the-first-bitcoin-ipol.

289. J.P \& G.T., supra note 44. 
accommodate these new types of businesses, close analogies will often be found in existing standards. Nothing about Bitcoin changes the fact that laundering money and buying narcotics are illegal in most countries around the globe.

There is no guarantee that Bitcoin will succeed. There are too many unknowable variables. It is possible, perhaps even likely, that a currently unknown competitor might overtake Bitcoin and replace it. One of the core developers of Bitcoin has stated that he would embrace this, as he supports competition and believes that it ultimately works for the best. 290 Whatever happens, one thing remains undeniable: the world is forever changing, and governments and businesses must stay abreast of these changes if they are to maintain their positions of power in the future.

290. Andresen, supra note 16. 